DOI: https://dx.doi.org/10.18203/2320-1770.ijrcog20210745

\title{
Prevalence of occult gynecological cancer in women undergoing surgeries for benign indications in a tertiary healthcare center of Chhattisgarh
}

\author{
Abha Singh ${ }^{1}$, Avinashi Kujur ${ }^{1}$, Renuka Ghahine ${ }^{2}$, Rashmi Tiwari ${ }^{1 *}$ \\ ${ }^{1}$ Department of Obstetrics and Genecology, Pt. J. N. M. Medical College, Raipur, Chhattisgarh, India \\ ${ }^{2}$ Department of Pathology, Rajnandgaon Government Medical College, Rajnandgaon, Chhattisgarh, India
}

Received: 26 January 2021

Accepted: 11 February 2021

\author{
*Correspondence: \\ Dr. Rashmi Tiwari, \\ E-mail: coolobgyian@gmail.com
}

Copyright: () the author(s), publisher and licensee Medip Academy. This is an open-access article distributed under the terms of the Creative Commons Attribution Non-Commercial License, which permits unrestricted non-commercial use, distribution, and reproduction in any medium, provided the original work is properly cited.

\begin{abstract}
Background: Hysterectomy, the surgical removal of uterus, is $2^{\text {nd }}$ most frequently performed major surgical procedures on women, with $90 \%$ of hysterectomies are performed for benign indications. However, there may be cases in which malignancy or premalignant lesions which are only confirmed on histopathology are defined as occult malignancy.

Methods: We conducted a prospective observational study on a cohort of women undergoing various gynaecological surgeries for benign indications in a time period of January 2019 to January 2020 in the Department of obstetrics and gynaecology, Dr. BRAM hospital and Pt. J. N. M. medical college, Raipur (C.G) to find out the prevalence of occult pre malignant and malignant lesions.

Results: Of 132 women who underwent surgeries for benign gynecological indications, based on final histopathological report, prevalence of occult premalignant lesion was $11.36 \%$ (95\% CI 5.7-16.3\%) and prevalence of occult malignancy was $2.27 \%$ (95\% CI $0.2-4.8 \%$ ). Prevalence of occult premalignant lesion of corpus uteri and cervix uteri was 2.3 and $9.1 \%$ respectively. No occult premalignant lesion of ovary was found. Prevalence of occult malignant lesion of corpus uteri and ovary was 1.5 and $0.75 \%$ respectively.

Conclusions: We observed that even after complete preoperative workup only $72.7 \%$ of the preoperative clinical diagnoses were correlated with their histopathological diagnosis. Thus, while making the diagnosis, risk factors along with standard preoperative approach should be strongly adhered to prevent misdiagnosis and to prevent missing of any pre malignant or malignant findings.
\end{abstract}

Keywords: Benign indications, Hysterectomy, Myomectomy, Occult malignancies, Risk factors

\section{INTRODUCTION}

Hysterectomy, the surgical removal of uterus, is $2^{\text {nd }}$ most frequently performed major surgical procedures on women all over the world, next only to cesarean. ${ }^{1}$ Hysterectomy and myomectomy are common gynecological procedures with more than 600,000 and 43000 surgeries performed yearly in U.S respectively. ${ }^{2}$

Nearly $90 \%$ of hysterectomies are performed for benign indications, whereas myomectomies are performed only for benign indications (like uterine fibroid). ${ }^{2}$ Common indications of hysterectomy are benign gynecological conditions like uterine leiomyoma (40.7\%), endometriosis (17.7\%), uterine prolapse (14.5\%), endometrial hyperplasia $(2.7 \%)$, rest all other benign conditions (15.2\%); and cancer $(9.2 \%){ }^{1}$

However, there may be cases in which uterine, cervical or tubo-ovarian malignancy or premalignant lesions which are confirmed on surgical histopathology but did not have clinical preoperative suspicion of malignancy. Such cases can be defined as occult malignancy. ${ }^{3}$ Current evidence on the risk of occult uterine malignancy remains highly 
variable with estimated prevalence ranging from 0 to $3.17 \%$ across studies and through present study we want to emphasize that though occult malignancy is rare but not nonexistent. ${ }^{2,3,6,12}$

The present study is aimed to estimate the prevalence of preoperatively undiagnosed occult malignancy and pre malignant lesions of corpus uterus, cervix uteri, and ovaries in women undergoing gynecological surgeries for benign indications.

Aims and objectives of the study were to find the prevalence of occult malignant and premalignant gynecological lesions among the women who underwent surgeries for benign indications and had a normal preoperative workup, in a tertiary healthcare setup of Chhattisgarh.

\section{METHODS}

We conducted a prospective observational study on a cohort of women undergoing various gynecological surgeries for benign indications in a time period of January 2019 to January 2020 in the department of obstetrics and gynecology of Dr. Bhim Rao Ambedkar memorial hospital and Pt. J. N. M. medical college, Raipur (C.G) after approval from institutional scientific and ethical committee.

Our primary outcome measure was the prevalence of occult malignancy and pre malignant lesions of the corpus uteri, cervix uteri, and ovary. Woman's sociodemographic profile and clinical characteristics were analyzed for the risk assessment.

\section{Inclusion criteria}

All the women of age more than 30 years getting admitted in gynecology wards of Dr. B. R. Ambedkar memorial hospital Raipur for gynecological surgeries of benign indications.

\section{Exclusion criteria}

The patient with diagnosed or suspected malignancy before beginning of surgery.

Standard preoperative workup included laboratory tests such as complete blood count, liver and renal function test, random blood sugar, coagulation profile, urine routine-microscopy, lipid profile; detailed physical examination of abdomen and pelvis; complete gynecologic examination including pap smear, vaginal culture; bimanual and rectovaginal examination in case of genital organ prolapse; ultrasonography of abdomen and pelvis and MRI or CT scan of abdomen and pelvis was done to help in making diagnosis in cases of suspected malignancy. Tumor markers such as $\mathrm{CA}_{125}, \mathrm{CA}_{19.9}$, human chorionic gonadotropin, $\mathrm{LDH}$, alpha fetoprotein was sent and histopathological examination of endometrial sampling and biopsy of selected cases was done. Chest x ray and ECG was done and medical and anesthesia fitness was taken for proposed procedure.

The postoperative surgical specimens were sent for histopathological examination and diseases reclassified in benign, pre malignant and malignant based on final histopathology report.

We studied clinico-pathological correlation between the pre-operative clinical diagnosis and post-operative diagnosis based on final histopathology report to find out the sensitivity of standard preoperative workup and to find the positive predictive values of standard preoperative tests in predicting risk of occult premalignant and malignant lesion.

\section{Statistical analysis}

We have estimated the $95 \%$ confidence intervals based on binomial distribution and calculated the odds ratios to find the association between available patient characteristics and the presence of occult pre malignant and malignant lesion. The significant association was defined by the $\mathrm{p}$ value of less than 0.05 ( $\mathrm{p}$ value $<0.05$ ).

\section{RESULTS}

Among 26,179 women who attended the gyne OPD of Dr. B. R. A. M. hospital, Raipur (C.G) from January 2019 to January 2020, total 132 women met our eligibility criteria.

In our study, the most common surgery performed during study period was hysterectomy (78.8\%). Among hysterectomies, most common hysterectomy performed was total abdominal hysterectomy $(37.1 \%)$ followed by nondescent vaginal hysterectomy (12.8\%), vaginal hysterectomy $(11.4 \%)$ and vaginal hysterectomy with pelvic floor repair (6.06\%). 2.2\% women had laparoscopy assisted vaginal hysterectomy and $0.75 \%$ had subtotal hysterectomy. Total $9.1 \%$ women had undergone TAH with BSO and $2.3 \%$ had TAH with unilateral salpingooophorectomy in our study, as per our institutional norms to preserve ovaries in accordance to ACOG criteria of ovarian preservation till the age of 65 year.

Second most common surgery was myomectomy performed for fibroid uterus $(6.8 \%)$ followed by ovarian cystectomy $(4.5 \%)$ and hysteroscopic polypectomy $(4.5 \%)$. Salpingectomy alone was done in $3 \%$ women and salpingooophorectomy was performed in $1.5 \%$ women. Unilateral salpingectomy with cystectomy was performed in $0.75 \%$ women.

We have observed that only $72.7 \%$ of preoperative clinical diagnosis was correlated with histopathological diagnosis. Most common missed diagnosis was adenomyosis (it was missed in $6.06 \%$ women) followed 
by endometrial hyperplasia (in 3.0\%) and leiomyoma (in $2.27 \%$ ) (Table 1).

Out of all the surgery performed, $86.36 \%$ women had benign lesion on histopathological examination.3.9\% of the women with leiomyoma, $22.2 \%$ of the women with adenomyosis, $3.3 \%$ of the women with endometrial hyperplasia, $29.4 \%$ of the women with genital organ prolapse and $11.1 \%$ of the women with endometrial polyp had occult pre malignant lesion in their histopathological examination report. Most common occult premalignant lesion was HSIL $(80 \%)$ followed by endometrial hyperplasia with atypia (20\%) (Table 2).

$6.7 \%$ of women with endometrial hyperplasia, $33.3 \%$ of women with benign tubo-ovarian mass and $33.3 \%$ of the women with gestational trophoblastic disease had occult malignant lesion in their histopathological examination report i.e., carcinoma endometrium IIIb, dysgerminoma of ovary and choriocarcinoma respectively (Table 3 ). Figure 1, 2 and 3 depict gross and microscopic view of occult malignant lesions of our study.

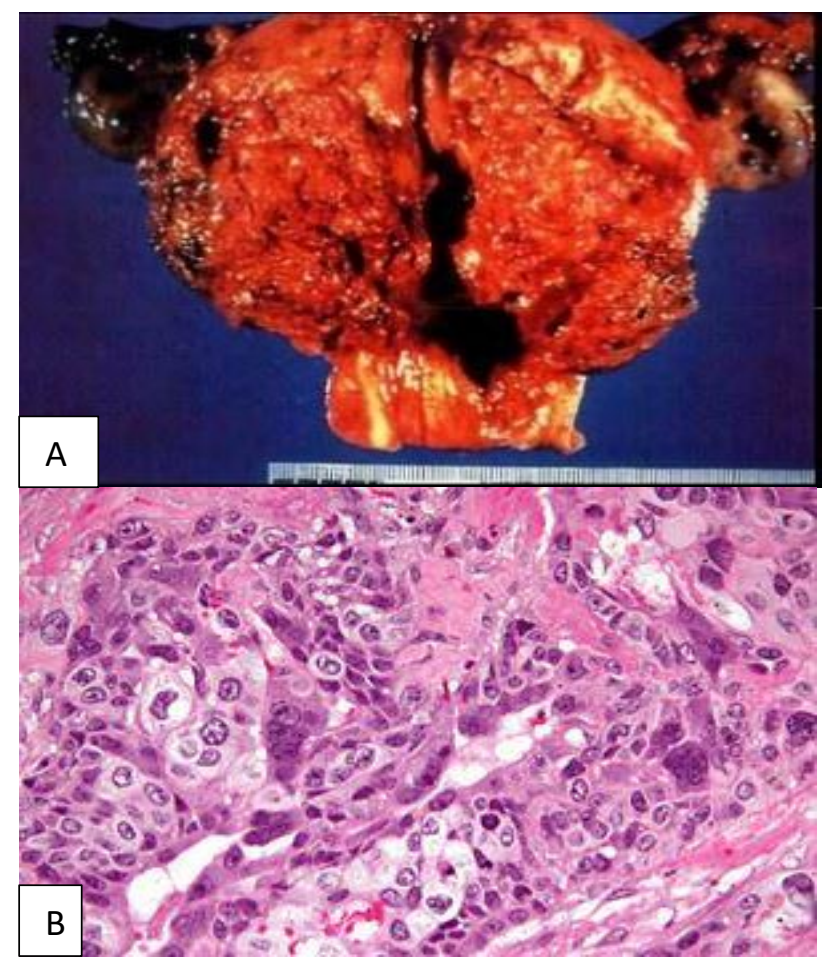

Figure 1: Choriocarcinoma.

$86.7 \%$ women with occult pre malignant lesion had some risk factors associated for that lesion whereas $100 \%$ women with occult malignant lesion had some risk factors associated.

In our study protocol, the sensitivity of bio-physical investigation (Table 4 and 5) (which included, PAP smear, colposcopy, hysteroscopy, laparoscopy, endometrial aspiration) was highest $(92.8 \%)$ followed by physical-radiological investigations $(83.3 \%)$ and then bio-chemical investigations $(75.0 \%)$.

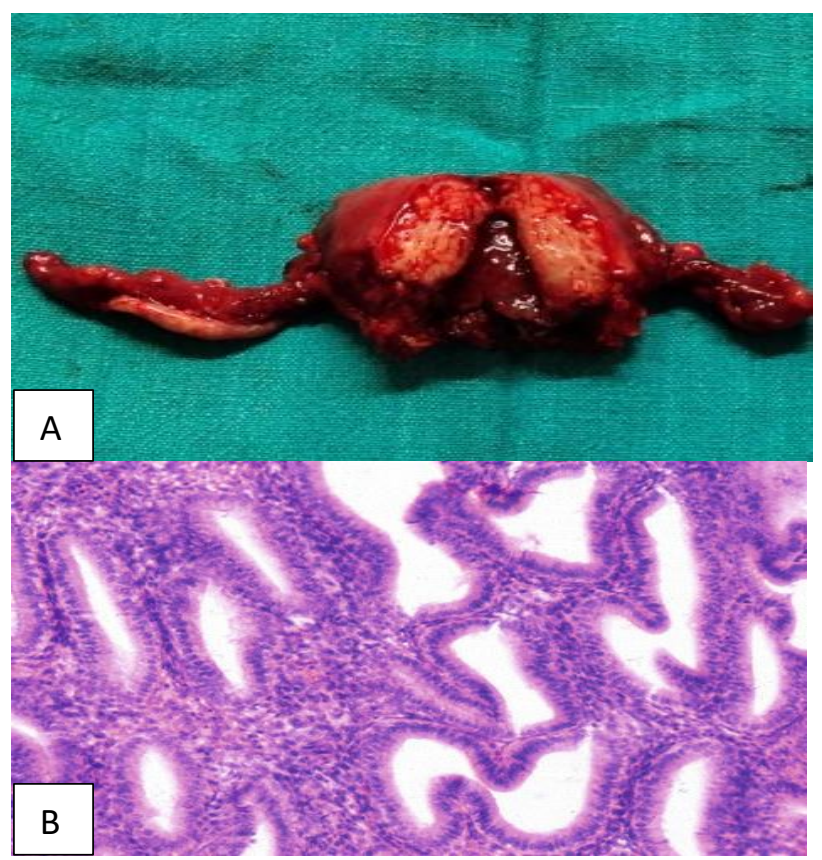

Figure 2: Endometrial carcinoma.

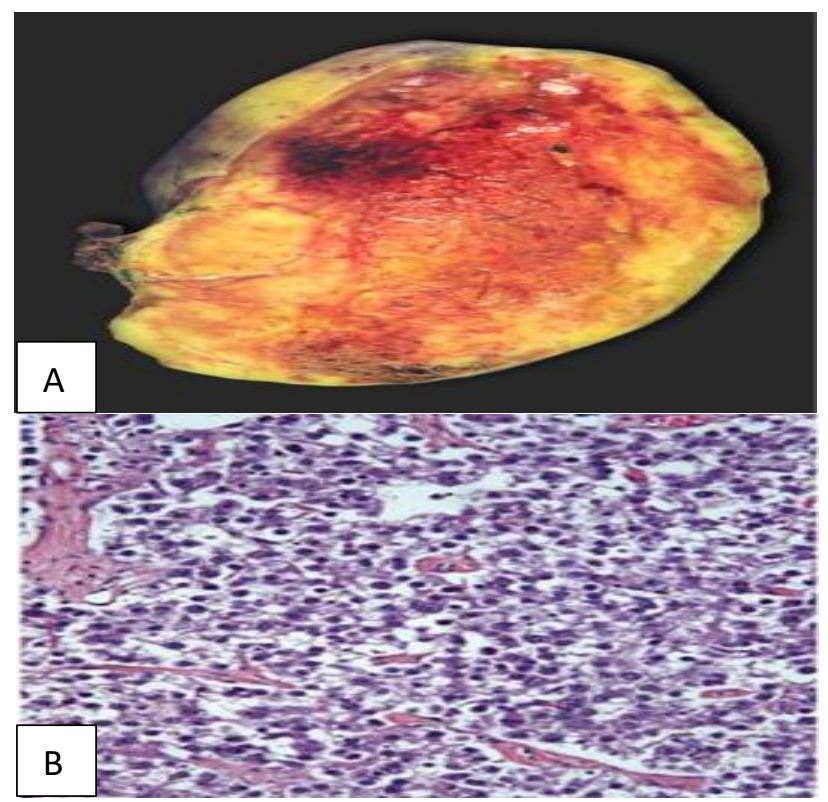

Figure 3: Ovarian dysgerminoma.

Of all women who underwent surgeries for benign gynecological indications, based on final histopathological report, prevalence of occult premalignant lesion was $11.36 \%$ (95\% CI 5.7-16.3\%) and prevalence of occult malignancy was $2.27 \%$ (95\% CI $0.2-$ $4.8 \%$ ). Prevalence of occult premalignant lesion of corpus uteri and cervix uteri was 2.3 and $9.1 \%$ respectively. No occult premalignant lesion of ovary was found. Prevalence of occult malignant lesion of corpus uteri and ovary was 1.5 and $0.75 \%$ respectively. 
Table 1: Distribution of women according to type of histopathological finding.

\begin{tabular}{|lllll|}
\hline $\begin{array}{l}\text { Pre-operative } \\
\text { diagnosis }\end{array}$ & $\begin{array}{l}\text { Total } \\
\text { number }\end{array}$ & $\begin{array}{l}\text { Benign } \\
\text { histopathological } \\
\text { findings } \\
(\mathbf{n}=\mathbf{1 1 4})(\mathbf{8 6 . 4 \%})\end{array}$ & $\begin{array}{l}\text { Pre malignant } \\
\text { histopathological } \\
\text { finding } \\
(\mathbf{n}=\mathbf{1 5})(\mathbf{1 1 . 3 6 \%})\end{array}$ & $\begin{array}{l}\text { Malignant } \\
\text { histopathological } \\
\text { finding } \\
(\mathbf{n}=\mathbf{3})(\mathbf{2 . 2 7} \%)\end{array}$ \\
\hline Leiomyoma & 51 & $49(96.0)$ & $02(3.9)$ & None \\
\hline $\begin{array}{l}\text { Adenomyosis } \\
\text { Endometrial } \\
\text { hyperplasia }\end{array}$ & 09 & $07(77.8)$ & $02(22.2)$ & None \\
\hline $\begin{array}{l}\text { Genital organ } \\
\text { proplapse }\end{array}$ & 15 & $09(60.0)$ & $05(33.3)$ & $01(6.7)$ \\
\hline Endometrial polyp & 09 & $08(88.9)$ & $05(29.4)$ & None \\
\hline $\begin{array}{l}\text { Endometriosis } \\
\text { Benign ovarian } \\
\text { cyst }\end{array}$ & 05 & $05(100)$ & $01(11.1)$ & None \\
\hline Tubo-ovarian mass & 03 & $13(100)$ & None & None \\
\hline $\begin{array}{l}\text { Gestational } \\
\text { trophoblastic } \\
\text { disease }\end{array}$ & 03 & $02(66.7)$ & None & $01(33.3)$ \\
\hline Chronic PID & 02 & $02(66.7)$ & None & $01(33.3)$ \\
\hline
\end{tabular}

Table 2: Women with occult premalignant lesions on histopathological examination ( $n=15)$.

\begin{tabular}{|lll|}
\hline Clinical diagnosis & Surgery & Premalignant finding on HPE \\
\hline Third degree uterine prolapse-5 cases & VH & HSIL (CIN II) of cervix \\
\hline AUB-M & NDVH & Endometrial hyperplasia with atypia \\
\hline AUB-M & NDVH & Cervix- HSIL (CIN II) \\
\hline AUB-M with right ovarian dermoid cyst & TAH with BSO & Cervix- HSIL (CIN II) \\
\hline AUB- A, M & TAH & Endometrial hyperplasia with mild atypia \\
\hline Fibroid uterus & TAH & $\begin{array}{l}\text { Cervix- HSIL (CIN II) with squamous } \\
\text { metaplasia }\end{array}$ \\
\hline Adenomyosis & NDVH & Cervix- HSIL (CIN III) \\
\hline AUB-A with right ovarian cyst & TAH with salpingectomy & Cervix- HSIL with chronic cervicitis \\
\hline Fibroid uterus & TAH & Endometrial hyperplasia with mild atypia \\
\hline AUB-M with cystocele with rectocele & TAH & $\begin{array}{l}\text { Cervix-HSIL (CIN II) with chronic } \\
\text { cervicitis }\end{array}$ \\
\hline AUB-P, $\mathbf{L}$ & TAH & Cervix- HSIL (CIN II) \\
\hline
\end{tabular}

Table 3: Women with malignant lesion on histopathological examination $(n=3)$.

\begin{tabular}{|c|c|c|c|}
\hline Clinical diagnosis & Surgery & Histopathological finding & Final diagnosis \\
\hline $\begin{array}{l}\text { Persistent gestational } \\
\text { trophoblastic disease }\end{array}$ & TAH & $\begin{array}{l}\text { Evacuation s/o invasive mole } \\
\text { Hysterectomy specimen-s/o features of } \\
\text { choriocarcinoma }\end{array}$ & choriocarcinoma \\
\hline $\begin{array}{l}\text { Endometrial } \\
\text { hyperplasia }\end{array}$ & $\begin{array}{l}\text { TAH with } \\
\text { BSO }\end{array}$ & $\begin{array}{l}\text { Endometrium- well differentiated } \\
\text { hyperplasia with nuclear atypia with } \\
\text { areas of necrosis and lymphocytic } \\
\text { infiltration } \\
\text { Myometrium- myometrial invasion of } \\
\text { endometrial gland present s/o } \\
\text { malignancy } \\
\text { Cervix- hyperplasia, cervicitis }\end{array}$ & Carcinoma endometrium stage IIIB \\
\hline $\begin{array}{l}\text { Benign tubo-ovarian } \\
\text { mass }\end{array}$ & $\begin{array}{l}\text { TAH with } \\
\text { right salpingo- } \\
\text { oophorectomy }\end{array}$ & $\begin{array}{l}\text { Right ovary- mixed germ cell tumor s/o } \\
\text { dysgerminoma }\end{array}$ & Dysgerminoma \\
\hline
\end{tabular}


Table 4: Distribution of women according to standard pre-operative workup and correlation of clinical diagnosis with final histopathological diagnosis.

\begin{tabular}{|c|c|c|c|c|c|c|c|c|}
\hline $\begin{array}{l}\text { Pre-operative } \\
\text { clinical diagnosis }\end{array}$ & $\begin{array}{l}\text { Bio- } \\
\text { chemical } \\
\left(\text { CA }_{125},\right. \\
\text { CA19.9, } \\
\text { LDH, AFP, } \\
\text { Beta-hcg) }\end{array}$ & $\begin{array}{l}\text { Physical- } \\
\text { radiological } \\
\text { (physical } \\
\text { examination, USG, } \\
\text { MRI/CT) }\end{array}$ & $\begin{array}{l}\text { Biophysical } \\
\text { (PAP smear, } \\
\text { colposcopy, } \\
\text { hysteroscopy, } \\
\text { laparoscopy, } \\
\text { endometrial } \\
\text { aspiration) }\end{array}$ & $\begin{array}{l}\text { Total no. } \\
\text { of cases }\end{array}$ & $\begin{array}{l}\text { Correct } \\
\text { diagnosis by } \\
\text { standard } \\
\text { preoperative } \\
\text { workup }(\%)\end{array}$ & $\begin{array}{l}\text { Incorrectly } \\
\text { diagnosed on } \\
\text { standard } \\
\text { preoperative } \\
\text { workup }(\%)\end{array}$ & $\begin{array}{l}\text { Standard } \\
\text { preoperative } \\
\text { workup missed the } \\
\text { diagnosis }(\mathrm{n})(\%)\end{array}$ & $\begin{array}{l}\text { Occult } \\
\text { premalignant } \\
\text { or malignant } \\
\text { lesion }(\%)\end{array}$ \\
\hline Leiomyoma & yes & yes & & 51 & $44(86.3)$ & 07 (13.7) & 03 (2.27) & $02(1.5)$ \\
\hline Adenomyosis & & yes & & 09 & $07(77.8)$ & $02(22.2)$ & $08(6.06)$ & $02(1.5)$ \\
\hline $\begin{array}{l}\text { Benign } \\
\text { endometrial } \\
\text { hyperplasia }\end{array}$ & yes & yes & yes & 18 & $12(66.7)$ & $06(33.3)$ & $04(3.0)$ & $06(4.5)$ \\
\hline $\begin{array}{l}\text { Genital organ } \\
\text { proplapse }\end{array}$ & & yes & yes & 17 & $17(100.0)$ & - & - & $05(3.8)$ \\
\hline $\begin{array}{l}\text { Endometrial } \\
\text { polyp }\end{array}$ & & yes & yes & 09 & 07 (77.7) & $2(22.2)$ & - & $01(0.75)$ \\
\hline Endometriosis & yes & yes & yes & 05 & $05(100)$ & - & - & - \\
\hline $\begin{array}{l}\text { Benign ovarian } \\
\text { cyst }\end{array}$ & yes & yes & & 13 & $13(100)$ & - & - & - \\
\hline $\begin{array}{l}\text { Tubo-ovarian } \\
\text { mass }\end{array}$ & yes & yes & yes & 03 & $02(66.7)$ & $01(33.3)$ & - & $01(0.75)$ \\
\hline $\begin{array}{l}\text { Gestational } \\
\text { trophoblastic } \\
\text { disease }\end{array}$ & yes & yes & yes & 03 & $02(66.7)$ & $1(33.3)$ & - & $01(0.75)$ \\
\hline Chronic PID & & yes & yes & 08 & $08(100)$ & - & - & - \\
\hline
\end{tabular}

Table 5: Sensitivity and positive predictive value of standard pre-operative workup.

\begin{tabular}{|c|c|c|}
\hline Standard pre-operative workup & $\begin{array}{l}\text { Sensitivity of the } \\
\text { test }(\%)\end{array}$ & $\begin{array}{l}\text { PPV for predicting risk of pre malignant or malignant } \\
\text { lesion }(\%)\end{array}$ \\
\hline Biochemical (CA ${ }_{125}, \mathrm{CA}_{19.9}, \mathrm{LDH}, \mathrm{AFP}$, Beta-hcg) & 75 & 11.1 \\
\hline Physical-radiological (physical examination, USG, MRI/CT) & 83.3 & 12.8 \\
\hline $\begin{array}{l}\text { Biophysical (PAP smear, colposcopy, hysteroscopy, laparoscopy, } \\
\text { endometrial aspiration) }\end{array}$ & 92.8 & 27 \\
\hline
\end{tabular}


Table 6: Statistical association between characteristics of women and the risk of having occult gynecological cancer in surgical specimen and its significance.

\begin{tabular}{|c|c|c|c|c|c|}
\hline Characteristic & $\mathbf{N}$ (prevalence) & $\begin{array}{l}\text { Odds } \\
\text { ratio^}^{\wedge}(\mathrm{OR})\end{array}$ & $\begin{array}{l}95 \% \\
\text { confidence } \\
\text { interval }\end{array}$ & P value & $\begin{array}{l}\text { Statistical } \\
\text { significance }^{+}\end{array}$ \\
\hline \multicolumn{6}{|l|}{ Age (year) } \\
\hline 45 or less & $83(10)$ & 0.70 & $0.25-1.91$ & 0.49 & \multirow{2}{*}{ Not significant } \\
\hline More than 45 & $49(08)$ & 1.42 & $0.52-3.80$ & & \\
\hline \multicolumn{6}{|l|}{ Locality } \\
\hline Rural & $59(13)$ & 3.8 & $1.28-11.51$ & 0.016 & \multirow{2}{*}{ Significant $^{+}$} \\
\hline Urban & $73(05)$ & 0.26 & $0.08-0.77$ & & \\
\hline \multicolumn{6}{|l|}{ Education } \\
\hline Up to primary school & $60(14)$ & 5.17 & $1.60-16.70$ & 0.006 & \multirow{2}{*}{ Significant $^{+}$} \\
\hline Middle school and above & $72(04)$ & 0.19 & $0.05-0.62$ & & \\
\hline \multicolumn{6}{|l|}{ Socio economic status } \\
\hline Class I/II & $22(01)$ & 0.26 & $0.03-2.06$ & 0.20 & \multirow{2}{*}{ Not significant } \\
\hline Class III/IV/V & $110(17)$ & 3.83 & $0.48-3.04$ & & \\
\hline \multicolumn{6}{|l|}{ Parity } \\
\hline $\mathrm{P}_{0 / 1 / 2}$ & $66(05)$ & 0.23 & $0.07-0.77$ & 0.016 & \multirow{2}{*}{ Significant $^{+}$} \\
\hline$P_{>=3}$ & $66(13)$ & 4.17 & $1.29-13.45$ & & \\
\hline \multicolumn{6}{|l|}{ Hormonal status } \\
\hline Pre-menopausal & $100(14)$ & 1.13 & $0.34-3.74$ & 0.82 & \multirow{2}{*}{ Not significant } \\
\hline Post-menopausal & $32(04)$ & 0.87 & $0.26-2.88$ & & \\
\hline \multicolumn{6}{|l|}{ Route of surgery } \\
\hline Abdominal & $91(10)$ & 0.50 & $0.18-1.40$ & 0.19 & \multirow{2}{*}{ Not significant } \\
\hline Vaginal & $41(08)$ & 1.96 & $0.71-5.41$ & & \\
\hline \multicolumn{6}{|c|}{ Weight of uterus (hysterectomy specimen) (gm) } \\
\hline 150 or less & $63(11)$ & 1.35 & $0.48-3.80$ & 0.55 & Not significant \\
\hline More than 150 & $40(07)$ & 0.73 & $0.26-2.05$ & & \\
\hline \multicolumn{6}{|l|}{ Medical condition } \\
\hline Hypertension & $15(02)$ & 0.97 & $0.20-4.71$ & 0.97 & Not significant \\
\hline Hypothyroidism & $04(01)$ & 2.17 & $0.21-22.1$ & 0.51 & Not significant \\
\hline PID & $09(02)$ & 3.61 & $0.81-15.9$ & 0.09 & Not Significant \\
\hline Tobacco addiction & $32(05)$ & 1.23 & $0.40-3.79$ & 0.70 & Not significant \\
\hline
\end{tabular}

\section{DISCUSSION}

In our study, prevalence of occult premalignant lesion of corpus uteri and cervix uteri was 2.3 and $9.1 \%$ respectively, and prevalence of occult malignant lesion of corpus uteri and ovary was 1.5 and $0.75 \%$ respectively which is comparable to similar studies in past. ${ }^{2,4,5}$ But the prevalence is slightly lower in some other studies. ${ }^{6,7}$

We observed a particular higher risk of occult premalignant and occult malignant lesions in women with older age group.ie $16.32 \%$ of women aged more than 45 year had occult pre malignant and malignant lesion as compared with $12.04 \%$ in those aged 45 year or less and more risk was associated with lower socioeconomic status. This is consistent with the prior studies by Desai, Mahnert, Sawke, Singh and Singh et al..$^{2,8-11}$

In present study vaginal route was more strongly associated with findings of occult pre malignant lesion on histopathology. But abdominal route has been shown to have higher risk of occult malignant changes. Kho Kimberly, Frick, and Wright et al also found similar results. $^{3,6,12}$ This difference may reflect firstly, the differences in the underlying cause of the surgery. For instance, women with prolapse often treated with vaginal hysterectomy and they have higher risk of premalignant changes but lower risk of occult malignancy. Secondly, the surgeon may prefer one route over the other based on their expertise and they may systematically select the patient for different types of surgeries based on their risk profile. $^{13,14}$

Among patients with occult premalignant and malignant lesions only $11.1 \%$ ( 2 women) had TAH with bilateral salpingo-oophorectomy and 5.5\% (1 woman) women had TAH with right salpingo-oophorectomy and these women had associated ovarian pathology or belonged to high-risk group. There is a decreasing trend of bilateral salpingooophorectomy all over the world which was mainly done in order to decrease risk of ovarian cancer and the age 
limit was 45 year. ${ }^{15,16}$ But the current scientific evidence suggest that elective oophorectomy is not advisable in majority of the women, as it may lead to higher risk of death from cardiovascular disease and hip fracture and higher incidence of dementia and Parkinson's disease. ${ }^{16-18}$

In present study, clinico-pathological correlation was only $72.7 \%$, consistent to prior studies. , $7,19,20^{\text {This }}$ suggests that the standard preoperative workup made for routine gynecological surgeries are not sufficient in predicting the cancerous lesions and they need standardized modifications. ${ }^{21,22}$ Ultimate final diagnosis is always made on histopathological examination which always has more sensitivity and specificity.

\section{Limitations}

As our study was time bound, conducted for a period of 1 year so our sample size was small and it was a single institution-based study. This limits the generalization of results of our study because for this large sample size and multicentric study is required.

\section{CONCLUSION}

We have seen that in most of the women with occult pre malignant or malignant lesions, risk factors were present but even then, prevalence of occult pre malignant lesion was $11.4 \%$ and prevalence of occult malignant lesion was $2.27 \%$. We have also seen that even after complete preoperative workup only $72.7 \%$ of the pre-operative clinical diagnoses were correlated with their histopathological diagnosis. Thus, while making the diagnosis, standard pre-operative approach should be strongly adhered to prevent any misdiagnosis and to prevent missing of any pre malignant or malignant after findings.

Hence more research is required in this field to develop more sensitive and cost-effective screening methods for better prevention of unknown malignancies and to identify them during their early stage for better patient care and management.

\section{Funding: No funding sources}

Conflict of interest: None declared

Ethical approval: The study was approved by the Institutional Ethics Committee

\section{REFERENCES}

1. Whiteman MK, Hillis SD, Jamieson DJ, Morrow B, Podgornik MN, Brett $\mathrm{KM}$ et al. Inpatient hysterectomy surveillance in the United States, 20002004. Obstet Gynecol. 2008;34.e1-7.

2. Desai VB, Wright JD, Schwartz PE, Jorgensen EM, Fan L, Litkouhi B et al. Occult Gynecologic Cancer in Women Undergoing Hysterectomy or Myomectomy for Benign Indications. Obstetr Gynecol. 2018;131(4):642-51.
3. Kho KA, Lin K, Hechanova M, Richardson DL. Risk of occult uterine sarcoma in women undergoing hysterectomy for benign indications. Obstetr Gynecol. 2016;127(3)468-73.

4. Ramachandran T, Sinha P, Subramanium. Correlation between Clinico-Pathological and Ultrasonographical findings in hysterectomy. $\mathrm{J}$ clin diag res. 2011;5(4):737-40.

5. Dhruw D, Chikhlikar K, Meshram A. Analysis of the Histopathological examination of lesions in hysterectomy specimens in a tertiary care hospital: A five-year study. J Dental Med Sci. 2019;18(4):31-9.

6. Frick AC, Walters MD, Larkin KS, Barber MD. Risk of unanticipated abnormal gynecologic pathology at the time of hysterectomy for uterovaginal prolapse. Am J Obstet Gynecol. 2010;202:507.e1-4.

7. Rather GR, Gupta Y, Bharhwaj S. Patterns of lesions in hysterectomy specimen: A prospective study. Department of pathology Govt. Medical College, Jammu. JK sci. 2013;15(2):63-8.

8. Mahnert N, Morgan D, Campbell D, Jhonston C, AsSanie S. Unexpected gynecological malignancy diagnosed after hysterectomy performed for benign indications. Obstet Gynecol. 2015;125(2):397-405.

9. Sawke NG, Sawke GK, Jain H. Histopathology findings in patients presenting with menorrhagia: A study of 100 hysterectomy specimen. J Midlife Health. 2015;6(4):160-3.

10. Singh P, Ticku A, Jamwal G. Histopathological Spectrum of Hysterectomy Specimens in Tertiary care hospital: A Prospective Study. 2017;4(8):85866.

11. Singh A, Arora AK. Why hysterectomy rate are lower in India? Indian $\mathrm{J}$ Community Med. 2008;33(3)196-7.

12. Wright JD, Desai VB, Gross CP, Hutchinson LM, Schwartz PE, Xu X. Prevalence, Characteristics and Risk factors of occult uterine cancer in presumed benign hysterectomy. Am J Obstetr Gynecol. 2019;221:39.e1-14.

13. Singh A, Bansal S. Vaginal hysterectomy for nonprolapsed uterus. $\mathrm{J}$ Obstet Gynecol India. 2006;56(2):152-5.

14. Seles FM, Indira R. Incidental gynecological malignancy in women who underwent hysterectomy for utero-vaginal prolapse: a 3-year institutional study. Int J Reprod Contracept Obstet Gynecol. 2018;7(9):3625-28.

15. Parker WH. Ovarian conservation versus Bilateral oophorectomy at the time of hysterectomy for benign disease. 2013;1-4.

16. Parker WH, Broder MS, Liu Z, Shoupe D, Farquhar C, Berek JS. Ovarian Conservation at the Time of Hysterectomy for Benign disease. Obstet Gynecol. 2005;106(2):219-26.

17. Shuster LT, Gostout BS. Grossardt BR, Rocca WA. Prophylactic Oophorectomy in Premenopausal Women and long-term health. Menopause Int. 2008;14(3):111-6. 
18. Parker W. Elective oophorectomy in the gynecological patients: When is it desirable? Curr. Opin. Obstet and Gynecol. 2007;350-54.

19. Khan R, Sultan H. How does histopathology correlate with clinical and operative findings in abdominal hysterectomy? JAFMC Bangladesh. 2010;6(2):17-20.

20. Ebinesh A, Sharada MS, Krishna MC. Clinicopathological correlation of abdominal hysterectomy specimens. Int J Sci Res. 2015;4(6).

21. Lilac G, Zivandinvio R, Petric A, Lilac V. Preoperative preparation of patients for gynecologic surgery. Sci J Faculty Med Nis. 2011;28(2):125-33.
22. Markham SM, Rock JA. Preoperative care. In: Rock JA, Johnes HW, eds. Te Linde's operative gynecology. $9^{\text {th }}$ ed. Philadelphia: Lippincott Williamse Wilkins. 2003;475-7.

Cite this article as: Singh A, Kujur A, Ghahine R, Tiwari R. Prevalence of occult gynecological cancer in women undergoing surgeries for benign indications in a tertiary healthcare center of Chhattisgarh. Int J Reprod Contracept Obstet Gynecol 2021;10:1120-7. 